\title{
MIR30C1 wt Allele
}

National Cancer Institute

\section{Source}

National Cancer Institute. MIR30C1 wt Allele. NCI Thesaurus. Code C162384.

Human MIR30C1 wild-type allele is located in the vicinity of 1p34.2 and is approximately 89 bases in length. This allele, which encodes MIR30C1 pre-miRNA, plays a role in the modulation of gene expression. 